Pp. 151-176

\title{
A Psychoanalysis Reading of Mary Turner's Character in Lessing's The Grass is Singing
}

\author{
Sofian Herouach \\ English Department \\ Faculty of Arts and Humanities \\ Dhar El Mehraz, Sidi Mohammed Ben Abdullah University \\ Fes, Morocco
}

\begin{abstract}
Lessing's work The Grass is singing sheds significant light on several socio-cultural, political, gender, feminist and psychological issues. Racism is probably one of the most important themes of the work. However, the psychological dimension of this novel is also predominant. This aspect is embodied mainly through the protagonist, Mary Turner. Mary's troubled experiences and unconscious accumulations cause her much suffering and pain in her adult life. The present study is an attempt to investigate the character of Mary from a psychoanalytic perspective. It aims to shed light on the variables that overlap during Mary's successive life stages to end up in her being murdered. In other words, the study analyses how the accumulated experiences of Mary's childhood past, reinforced by present hardships, led her to develop psychological complexes and act upon them to end in her tragic death. This study is important in the sense that it may help explaining numerous psychological disorders by referring them to childhood events and sociocultural factors. In other words, the present study builds on the following question: to what extent childhood events and socio-cultural troubles could lead to psychological traumas and disorders? Briefly, the study findings proved that Mary's traumatic childhood and its unconscious painful memories were determinant factors to manifest character aberrations like hatred and aggressiveness. Moreover, the study concludes that Mary's subsequent socio-cultural pressures intensified her psychological reactions until coincided with the avenging character, Moses who murders her.
\end{abstract}

Keywords: childhood, Mary Turner, psychology, psychoanalysis criticism, sexuality, the unconscious, the grass is singing, transference

Cite as: Herouach, S. (2020). A Psychoanalysis Reading of Mary Turner's Character in Lessing's The Grass is Singing. Arab World English Journal for Translation \& Literary Studies 4 (4) 151-176. DOI: http://dx.doi.org/10.24093/awejtls/vol4no4.11 


\section{Introduction}

Human beings miss to interpret a great deal of psychological problems like neurotic matters, hysteric traumas, misbehaviors, mental disorders, depression manifestations...etc. The present study attempts to provide a rationale for the occurrence of such psychological manifestations by shedding light on the character of Mary Turner in Lessing's The Grass is Singing. Studying this character helps understanding in depth the nature of several mental troubles of which we are unaware. Aided by modern psychoanalysis techniques, the study reaches to explain why Mary Turner was reacting violently to her entourage at her adult life. Mary's childhood painful events, added to her adult social matters incarnated mainly through a failure marriage, explains much of Mary's personality disorder. This analysis on Mary could apply to all human members who share similar experience patterns. Each one of us has gone through a past tradition, childhood stages, and puberty conditions. The present study is significant in the sense that it helps coming acquainted with the reasons of much of our daily behaviors and misbehaviors. The present paper elaborates on the following questions: to what extent infancy stages could determine human adult personality? To what extent the unconscious could interpret human restored conflicts and impulses into physical actions and aberrations? How does modern psychoanalysis equip us with the techniques of understanding our human nature and our personality dimensions?

From the eighteenth century up to the sixties and the seventies of the twentieth century, literary products were considered meaningfully self-contained and self- referential. In other words, the author of a particular fictional work was considered the creator of the meaning of that work. As Montgomery, M., Durant, A., Fabb, N., Furniss, T., \& Mills, S. (1992) state, "In the eighteenth century in particular, literary works were considered to be products of conscious intention" (Montgomery et al., 1992, p. 172). For example, New Criticism argues that the product of the text is within the text and has nothing to do either with the intention of the author or with the response of the reader. As Tyson (2006) puts, "The new critics believed that the timeless meaning of the text - what the text is- is contained in the text alone" (p. 162). However, this has started to change since the prevalence of reader-response criticism in the 60s and 70s of the twentieth century.

Since then, fictional products have become prone to different approach readings and analyses. In contrast to streams such as new criticism and formalism, reader-response criticism recognizes the reader as an active agent. In other words, this theory relates the text to the interpretation of the reader. Conditioned by certain socio-cultural and psychological experiences and factors, the receiver of the text is held free to complete its meaning. It focuses on the feelings and associations it creates to the receiver of the artistic work while submerged in the reading process. In this respect, Tyson (2006) emphasizes that what a text is cannot be separated from what it does (Tyson, 2006). Clearly, this current believes that the text meaning lies solely in what it does, not in what it is. Consequently, fiction works no longer reflect the intention of the author per see but are liable to respond to the vision and interpretation of the reader. In wide response to such thought currents, different approaches across different scientific fields are applied to various literary works. In this respect, the work of Doris Lessing (1950) alone could be adapted to different readings and studies. Perspectives such as feminism, sociology, gender, politics and psychoanalysis seem very

Arab World English Journal for Translation \& Literary Studies 
appropriate for such a rich-content manuscript. Thus, the work at hand sounds ripe and rich of psychological backgrounds to be approached psychologically.

The plot of the work The Grass is Singing, unfolds the troubled social and psychological fiber that develops towards the murder of the British white protagonist, Mary Turner. At first hand, Mary is introduced as a happy satisfied woman. She has a job and hangs out with housemates whose loyalty she had not doubted a while. Even if she had endured a great deal of painful events in her childhood, especially the cruelty of her father, she seemed not affected in her present life because she finds new friends, and she is very comfortable. Disappointed by her friend's subsequent infidelity revelation through a heard gossip, she started submerging in frustration feelings. The social pressure through her friend's perception of her as an unmarried woman pushed her to marry a failure husband, Dick Turner. Her life starts then undergoing a different course-line ever since, manifesting uncontrolled tirades to the entourage. She develops dire neurotic matters, obsessions and fears which are psychological motives that grow to the ultimate explosion, ending in getting killed by her houseboy, Moses.

One major motive behind approaching Mary's character from a psychoanalytic angle is referred to the precise portrayal of Mary by the author in psychological terms and intents. This entices readers, having the least background in modern psychology, to notice its rich psychological dimension. Moreover, the will of being more acquainted with psychoanalysis is another motive behind this choice. Being acquainted with psychoanalysis helps understanding complex scopes of the human character because a great deal of our acts and comportments, behaviors and demeanors can be explained through unconscious psychological backgrounds.

The aim of this study is investigating Mary's present motives and psychological projections by looking at her childhood past experiences from a psychological perspective. The approach of this study stands mainly on Freud's modern theory of psychoanalysis.

In general, the study is divided into two major parts. The first contains psychoanalysis foundation principles as a theoretical background; the second deals with the psychic life of Mary, her childhood, socio cultural conflicts, unconscious manifestations and her tragic death, approached psychologically. The first part sheds light on the studies conducted on the novel The Grass is Singing and tackles the scholarly bond between psychoanalysis and literature. It also involves psychoanalytic theory major foundations, subdivided into two subtitles: sexuality and personality, which will be useful in the analysis of the person Mary. The second part is considered a practical application of psychoanalysis to literature through the analysis of the character of Mary. It includes the following sections and subtitles: Childhood, Dream Interpretation, individual vs. Collective thought, Mary and the Unconscious and Mary and Death.

\section{Literature Review}

Different studies were conducted on the rich novel The Grass is Singing. Researchers worldwide opted to approach this epic work from different angles and perspectives. Some studies focused on the colonialist dimension of the novel. They tackle and criticize colonialism, its damage

Arab World English Journal for Translation \& Literary Studies 
to the indigenous people economically, politically and culturally and its threat to world peace nations. For example, a conducted study in 2017 entitled An Interpretation of Mary in the Shadow of Colonialism in Doris Lessing's-The Grass is Singing sheds light on the social dimension of the novel. It interprets the sufferance of the black people of Rhodesia during their subordination to the British colonization. In this regard, Zhang (2017) highlights how does the author convey discrimination and racism issues, "The Grass is Singing is Lessing's first novel that is set on the background of colonized southern Africa-Rhodesia; Lessing showed a vivid picture of colonialism to the readers" (pp. 55-60). Other works approached the novel from a feminist perspective. For example, Yahya (2010) demonstrates where in the text the author hinted to the social burden on women and their suffering in patriarchal societies (Yahya, 2010). He holds that by writing this novel, Lessing (1950) has tried to raise a new consciousness in terms of sufferings and problems that marriage and family unit may bring to the life of women (Yahya, 2010). On the other hand, some studies approached the novel The Grass is Singing from a psychoanalytic point of view.

Yet there is not found enough researches that worked on the psychological dimension of the novel. One significant study in this interest is done in 2015 entitled The Reality of the Fractured Psyche as Represented in Grass Is Singing. For example, in this article, Bagchi (2015) contends that Mary Turner is represented as undergoing a slow yet a gradual psychic degeneration. She holds that her isolation from everyone and her alienation characterized by pessimism leads her to a state of depression where she unknowingly fades into a phase of speechlessness as if her train of thought is getting derailed (Bagchi, 2015). Despite the fact that the above-mentioned work sheds light on some psychological symptoms of Mary, it does not refer to any psychological theories, ancient or modern to explain how Mary had the psyche fractured. In the same field of interest, the present study is an attempt to approach Mary from a psychoanalytic point of view. However, the paper at hand compared with the previous one is worked out to be characterized by more novelty and scientific credibility in the sense that it builds on foundations of modern psychoanalysis to explain Mary's behaviors and misbehaviors. Moreover, not only does the study provide a background legitimacy to analyze a fictional character psychologically but it also justifies the researcher's or the reader's legacy to freely read the text. This reader privilege in the treatment of the text is supported by literary Currents such as reader-response criticism. Clearly, the paper at hand refers to a solid background of psychoanalysis established by Sigmund Freud to approach Marry psychologically. Moreover, it delineates the link between literary works and psychoanalysis; whereas, the previous work did not hint to such backgrounds that would enable it further academic feasibility.

\section{Psychoanalysis and Literature}

Psychoanalysis Criticism

Psychoanalysis is a system of psychology theory that investigates the interaction of conscious and unconscious elements in the mind. Freud's solid start in psychoanalysis was embodied in his monumental achievement and success to explain hysteria symptoms psychologically. For example, Freud and Breuer (2004) hold that psychological matters such as hysteria have to be explained through studying the unconscious determinants of one's behavior. These unconscious

Arab World English Journal for Translation \& Literary Studies 
determinants may have a lot to do with our early childhood experiences. Being dissatisfied with physical accounts for hysteria provided by numerous doctors, Freud immersed in investigating one's past painful experiences to ascribe them the probability of hysterical occurrences. In other words, Freud attempted to listen to the past stories of his patients as a technique for understanding the root-causes behind their psychological problems. Such investigation is not purely random but it is based on scientific techniques and methods. These techniques are centered on three main concepts that are key terms to Freud's psychoanalysis: sexuality, personality and the unconscious. These concepts will be explored later in this work. Consequently, Freud discovered that there were mental processes behind hysterical problems that were not conscious (as cited in Thurschwell, 2000).

Since ever, Freud's psychoanalysis was considered a scientific revolution in the field of psychology. He concludes that humans are driven by desires, fears, needs and conflicts of which they are unaware and which are very likely to have been shaped by childhood events. Psychoanalysis is, therefore, interested in the hidden realm of the human being which is the unconscious and how it forms indirectly the human personality, how it controls certain behaviors, and how it may engender certain acts and demeanors. In other words, psychoanalysis delves into the human unconscious mechanisms and how they may operate to yield positive actions or negative dysfunctional behaviors.

In due relation, psychoanalysis criticism argues the relation between psychoanalysis and literature. Freud himself laid the foundations for psychoanalytic criticism that was elaborated on later by Jacques Lacan. For example, Das (2005) argued, "Since the 1920, a very widespread psychological type of literary criticism has come to be called psychoanalytic criticism, whose premises and procedures were established by Sigmund Freud (1856-1939)" (p. 105). Psychoanalytic criticism focuses on the extent to which literary works are likely to reflect the psychological dimension of the author, embodied in personages and characters. Clearly, this trend movement argues that the characters portrayed in the text could be themselves projections of the author's psyche. In other words, written art may be expressive of the secret unconscious desires and anxieties of the artist. For example, Appleman (2015) affirms, "Psychological criticism deals with a work of literature primarily as an expression, in fictional form, of the personality, state of mind, feelings and desires of the author" (p. 163).

For instance, Freud (1924) considered that literature and other arts consist of the fantasized fulfillment desires of the artist which are either denied by reality or are prohibited by the standards of morality established by society (Freud, 1924). These forbidden desires come into conflict with and are repressed by the censor (superego) into the unconscious realm of the artist's mind, but are permitted to achieve fantasized satisfaction in distorted or disguised forms (Abrams, 1999). Fiction, therefore, could be an appropriate scope where the author releases his unconscious impulses and repressed conflicts. Moreover, Freud believes that the unconscious also harbors stages of psychosexual development, from the earliest infancy onwards, which has been outgrown by the mature person, but remains as fixations in the unconscious (as cited in Randall, 1989). When activated by some later event, these fixations may be projected either in the mode of dreams or

Arab World English Journal for Translation \& Literary Studies 
neurotic symptoms. The chief enterprise of psychoanalytic criticism is to reveal the true content, and to explain the effect on the reader, of a literary work by translating its manifest elements back into their latent, unconscious determinants (Abrams, 1999).

Simply put, psychoanalytic criticism seeks into the motives of the artist's deep mind (latent content) to explain his present creative artistic product (manifest content). By doing so, it is assumed that author's creative fictional products may serve as therapeutic tools for the pathologies that the artist may be suffering. It is a field where the artist discharges his mental disturbances and unconscious repressions in a fictionalized fantasized manner. Yet the artist probable projection of his state of mind in fictional forms differs radically from the standard psychic manifestations of other common people. Abrams (1999) contended that the artist possesses abilities in addition to the universal human ability to fantasize and dream, and that these abilities serve to differentiate the artist radically from the patently neurotic personality (Abrams, 1999). Clearly, the artist differs with the commoner in the sense that he is able to shift his unconscious processes from purely instinctual drives to sublime objectives.

Unlike some persons whose unconscious motives could be projected in neurotic, paranoiac or hysteric matters, the artist manages to elaborate fantasized wish- fulfillment in a controlled manner that conceals its instinctual egoistic elements. Accordingly, the artist is enabled to overcome his personal conflicts and repression as well as he obtains solace and consolation from the audience's unconscious source through their reading process (Abrams, 1999). Therefore, a psychoanalytic approach to a work of art helps understanding the temperament and the psychological conditions of the artist and may explain the inner implications of the aesthetic work. As a case in point, the Freudian interpretation of Shakespeare's Hamlet does not only uncoverthe mysterious character of Hamlet, but it also helps discovering the deeper workings of Shakespeare's mind (Harris \& Scott, 1984). Similarly, the character of Mary may demonstrate strong signs for understanding the psychic life of the Author, Doris Lessing.

The psychological dimension of the work at hand is obvious through how the character of Mary is described by the author. Mary's present behaviors and feelings could be projections and reflections of her unconscious repressed conflicts. They may represent the painful experiences she went through in her life. First, Mary as a child was not brought up in a healthy social environment because she was often affected by the violence that was exerted on her mother by her father. Moreover, she was sexually harassed by her drunkard dad. Among the consequences of these effects is her developing a set of psychological matters and neuroses like anger, anxiety, isolation, unsociability, lack of interaction, violent reactions...etc. She becomes closed up, and endures serious psychological conflicts that appear in the form of transference and displacement of anger, and other psychoanalytic concepts that are useful in the analysis of this character.

\section{Pillars and Foundations of Modern Psychoanalysis}

Sexuality

Freud looks at sexuality as a natural and biological truth, which grows up and affects directly the growth of our personality. For example, Freud (2015) stated, "The fact of sexual need in man and 
animal is expressed in biology by the assumption of a sexual impulse, this impulse is made analogous to the impulse of taking nourishment and to hunger" (p. 151). For Freud, sexual development stages of infancy are the source behind a person's possible adult aberrations and perversions. Freud relates a great deal of adult neurotic and hysteric manifestations as well as obsessions and paranoiac matters to the psychosexual developmental stages of the child. Simply put, sexuality could influence positively or negatively our adult person. As Shaffer (2008) put, "Freud thought that sex was the most important of the instincts because he discovered that the mental disturbances of his patients often revolved around childhood sexual conflicts that they had repressed" (p. 43). Thus, in order for an individual to be healthy and normal, he must complete these stages successfully. Otherwise, there eventually develops a kind of abnormal behaviors if any of these stages is developed improperly.

Henceforth, the psychiatrist has to seek into the unconscious realm of his patients and diagnoses how much of child conflicts and desires it has repressed to understand the nature of these psychological problems. Freud divides these childhood stages that he sees very determinant to one's personality into five phases. These are oral, anal, phallic, latency and genital. Each stage of this represents a sexual drive (Libido in Freud's terms) of the child development. Freud gives much importance to the sexual energy in human beings, believing that this sexual store or libido never ceases even if it experiences some periods of latency (Freud, 2014). The sexual theory shows how adult personality is determined by childhood experiences. The first stage of the sexual development of the child is the oral. It spans from birth to one-year age. At this stage, the libidinal pleasure is derived from the infant's mother feeding and contact with her breast.

The infant's mouth here becomes the center of gratification. In other words, the mouth, the lips and the tongue are the referential sexual scope. Mouthful activities such as sucking and suckling come to satisfy the libidinal desire of the child. Shaffer (2008) asserted, "The sex instinct centers on the mouth, as infants derive pleasure from such oral activities as sucking, chewing, and biting" (p. 65). At this age, babies see their mothers as an extension of themselves. They imagine that the outside world will provide them with all what they need. They do not distinguish themselves as independent entities. Szeman and O'Bien (2017) affirmed, "Their inner world [Meaning children's] is defined by an unorganized collection of prima drives and instincts, with no conscious sense of themselves as separate from the world around them" (p. 153). Upon the child's immediate realization that the environment and mainly his mother are not an extension of his being, he gets ready for the second stage, the anal.

The anal stage follows the oral and lasts from two to four years. During this phase, the child becomes aware of himself as an independent being, starting the process of distinguishing between him and the others. Moreover, he starts displaying a desire of building communication with the outer world. In due regard, Szeman and O'Bien (2017) added, “A baby's eventual realization that the world (...), isn't merely an extension of themselves is both a traumatic break and the beginning of the process of socialization, marked by the management and containment of powerful contradictory impulses towards the other" (p. 154). On the other hand, the infant begins to incorporate signs of morality, manifested in his developed capacities of controlling and cleaning

Arab World English Journal for Translation \& Literary Studies 
his defecation and excretion. Shaffer (2008) confirmed, "Voluntary urination and defecation become the primary methods of gratifying the sex instinct" (p. 40). In other words, now pleasure is derived from expulsion and retention. That is, the psychic force-libido is turned towards oneself to form what is called self-love or narcissism. Coyne (1999) stressed, "The retention of feces constitutes the exaggeration and perseverance of the anal phase of development characterized by self-love and narcissism” (p. 1669).

Following this, the phallic or Oedipus stage that Freud analogized with the Oedipus complex takes place. Perhaps, it is the most important in Freud's sexual developmental stages. It mostly takes place between four to six years old, during which a boy discovers his genitals and derives pleasure from contact with it. It is in this third infantile development phase that children become aware of their bodies, the bodies of other male and female children and the bodies of their parents. In addition, it is at this stage that the psychosexual Oedipus complex is experienced. Here, male and female infants start gratifying physical curiosity by undressing and exploring each other's sexual organs, and so they learn about their sexual differences. It is also at this age in which malefemale rivalry is perceived and at which Freud develops the castration theory.

Simply, castration is defined as the fear to lose the penis for boys and the recognition of the loss of the penis for girls. After having previously identified with the mother as a sexual reference, the child now squelches his love for his mother in fear to be castrated by the strong father. In this regard, the boy remains ambivalent about his father's place in the family, which is manifested as fear of castration by the physically greater father" (Bullock \& Trombley, 1999). While boys develop castration anxiety, girls develop a jealousy about not having a penis. At this stage, children develop an incestuous desire for the opposite-sex parent (called the Oedipus complex for boys and Electra complex for girls)" (Tidd, 2004). That is to say, when a girl realizes that she does not have the sexual organ as that of her opposite sex, she imagines that she has been already castrated. This is why she initially identifies herself with the father expecting that he can give her a baby as a substitute for the penis. Worthy of addition is that at this stage, the child develops important defense mechanisms like repression and identification, preparing himself for the latent stage.

The latent stage turns up from the end of the phallic to puberty. It normally takes place from 6 years to twelve. As latency word signifies, this stage experiences a sort of extinction of the libido or rather a sort of moderation of the sexual drives. In other words, there is an apparent renouncement in the sexual or postponing interest of the child. As Louw, D. A., Van Ede, D. M., Louw, A. E., \& Botha, A. (1998) put, "It is [meaning the latent stage] characterized by the fact that no new erogenous zones appear" (p. 47). With the beginning of education, social values and moral standards predominate on other interests. That is to say, children repress their sexual feelings and expression and gain more interest in socio-cultural practices. As Shaffer (2008) argued, "The ego and superego continue to develop as the child gains more problem-solving abilities at school and internalizes societal values" (p. 39). This situation lasts stable as long as the child is undergoing the latent phase. Sooner, however, this changes. Upon entering the last stage in Freud's terms, the genital, there is a reawakening of the sexual drives.

Arab World English Journal for Translation \& Literary Studies 
The genital phase starts from puberty to maturity. This phase is usually subtracted into two periods. The first is called homoerotic which is marked with the libido concentration on children of the same sex. In other words, the child overlooks his heterosexual interests that society discourages at this early life and feels more comfortable with peers of the same sex. However, Freud believes that people have to move beyond it to heterosexual relations if their sexual development has been proper. As Bullough andBullough (1994) hold, "Although he [Freud] regarded homoerotic behavior as a normal part of growing up, he held that most individuals move beyond this stage into adult heterosexuality" (p. 222). The homoerotic is followed by the period of heterosexuality. The narcissistic drive here persists and it is expressed in love affairs as this intends to demonstrate the ability to attract members of the opposite sex. Yet the child learns well how to manage his sexual drives in socio-culturally accepted ways. The child at this stage has already developed controlling mechanisms to behave according to social norms and rules and not submitting randomly to sexual motives. These controlling mechanisms are brakes that represent the constitution of the Ego and Superego by the end of the latent stage. Louw D. A et al (1998) asserted, "But the difference is that adolescents now have a well-developed ego and superego. So, they are capable of more realistic thinking, and they have established a variety of social relationships outside the family" (p. 47).

Table 1. Psychosexual stages put simply

\begin{tabular}{|l|l|}
\hline \multicolumn{2}{|c|}{ Psychosexual Stages } \\
\hline Oral & Pleasure is centered in the mouth through sucking. \\
\hline Anal & Pleasure is in the anus, through curbing or expelling excretion. \\
\hline Phallic & $\begin{array}{l}\text { Pleasure is gained through discovering the genitals, rubbing and } \\
\text { masturbating them. }\end{array}$ \\
\hline Latent & The renouncement of sexual motivation takes place \\
\hline Genital & Sexual intercourse is exercised socially acceptable manners. \\
\hline
\end{tabular}

Freuds consistency in psychoanalysis is very important. In parallel explanation of the physical or the sexual developmental stages of the child, he accounts for a symbolic development of the person. This symbolic division of the person besides the sexual one has come to be called the Freudian tripartite: Id, Ego and Superego. These are systems and not physical parts in the brain. Each develops at a certain age of the child besides his physical development. The Id simply represents the sexual instinctual demand. The Ego stands for reality demands. The Superego, on the other hand, stands for the ideal part; like a super judge of the mistakes of the Id and the Ego. These parts are going to be explored in the next section with the term "Personality", which is very significant to Freud's psychoanalysis.

\section{Personality}

Human personality in Freud's account develops from the interaction of the three symbolic parts mentioned above, the Id, Ego and Superego. These terms are topographical concepts within our minds. They are imaginary and symbolic concepts about the mind, and they are important in the 
sense that they help us understand how the structures of the psyche are inter-related. The first part, the Id, is simply the instinctual desire of the human being. According to Freud, the symbolic mental structure (the Id) is explained as an amorphous unorganized set of desires and whims. Freud confirmed,

The Id contains everything that is inherited, that is present at birth. It is laid down in the constitution above all, therefore, the instincts, which originate from the somatic organization, and which find a first psychical expression here in forms unknown to us (as cited in Gabriel, 1999, p.15).

In other words, the Id is an unstructured part, which does not care about reality. For example, when you are hungry, it is instinctual that you seek food. It is the same when you are thirsty. Your need has to be fulfilled.

In this regard, Parackal andPanicke (2019) added, "The id (...), consists of all the inherited components of personality present at birth, including the sex (life) instinct - Eros (which contains the libido), and the aggressive (death) instinct - Thanatos" (p. 243). Clearly, this part of the psychological structure seeks constant and immediate gratification of desires. The Id acts according to the pleasure principle, which is the idea that needs should be met immediately (Cherry, 2019). It centers on desires satisfaction and is careless to repercussions even when it happens to the detriment of the person himself. Examples in which excessive desire gratification out of Id demands caused destructive results are numerous. For instance, many people pass out and perish of overdose drug use even when they are very aware of the risk at their hand (ego tries control and mediation). It applies also to different other addictions, like sexual ones, masturbation habits...etc. That's to say, the Id pays no attention to social morals or values, and it does not make plans for the future. It just wants everything, which is good now with no consideration of time and other wishes. Worthy of notice is that the Id is the major part in the tripartite triangular of the personality, the Id, Ego and Superego.

As soon as Ego and Superego develop, the Id resides in the unconscious mind. All the desires that used to be gratified out of the Id demands are now repressed and transferred to the unconscious. The Ego is defined as a responsive tool to the demands of reality (Basler, 1948). The Ego develops when the child starts interacting more and more with the outside world. The ego is that part of the id, which has been modified by the direct influence of the external world (Freud, 1923). This corresponds with the phallic stage of the child's sexual development highlighted above. This means that once the child starts inserting social values and habits, his Id instincts are no longer granted the previous satisfactions. Unlike the Id that acts according to the pleasure principle, the Ego acts according to reality principles. However, it does not mean that the Ego omits all pleasures but it constructs a strategy to obtain them in realistic manners. It is considered as the organizer of the mind that tries to mediate between the Id and reality. Moreover, in order to control and lessen the Id's conflict with reality, the Ego employs defense mechanisms, which are developed by Freud as the following: repression, denial, displacement, intellectualization, fantasy, compensation, projection, rationalization, regression and sublimation (as cited in Plutchik, 1980).

Arab World English Journal for Translation \& Literary Studies 
These ego defenses, if not effectively deployed, can be destructive, and they can lead to problems in one's life.

Corresponding to the Oedipus complex during the phallic stage, the super-ego develops as our super moral stage. The Super Ego is referred as the self-critical aspect of the Ego. It incorporates values and morals it receives from parents and the society as a whole. Moreover, it serves as a judge on the conscious and the unconscious decisions of the Id and the Ego alike, and it includes the ego ideals that prohibit the immediate realization of the instinctual desires. If the Id wants only self-gratification, the Superego, on the other hand, attempts to act in a socially appropriate way, and it helps us behave according to the norms existing in our society. For example, it watches the Ego's actions and punishes it when it overpasses limits by imposing on it feelings of guilt and regrets. Carducci (2009) asserted, "The Superego punishes the ego in the form of guilt feelings, embarrassment, shame, or loss of self-respect" (p. 85). Furthermore, Freud claimed that the Superego is a symbolic internalization of the cultural regulations and the father figure. Freud emphasized,

The super-ego retains the character of the father, while the more powerful the Oedipus complex was and the more rapidly it succumbed to repression, the stricter will be the domination of the super-ego over the ego later on in the form of conscience and perhaps of an unconscious sense of guilt (as cited in Pannenberg, 1985, p. 195).

In other words, the superego tries to near perfection by forcing the Ego not only to moderate its excessive lusts and instincts but also to strive for moralistic and ethical ends. For example, religious practices of pious men and their striving to refrain from physical desires show the Superego higher goals of nearing perfection. Consequently, the interaction among these structures [Id, Ego, Super Ego] often results in both normal and abnormal behaviors. For example, when the ego is controlled by the demands of the Id and the Superego, a person can develop some unacceptable or irrational behaviors, which can weaken or rather collapse the ego strength, and it eventually results in the development of neurosis as a serious psychological conflict. In a word, the dynamic interaction between these basic parts of the mind carry human beings through the five psychosexual stages of development mentioned previously which include oral, anal, phallic, latency and genital. Thus, our daily actions as well as our dreams are results of the sort of interaction between these elements. Accordingly, the interaction between these parts is responsible for a great deal of our behaviors. From this psychoanalysis background of child psychosexual development and the development of personality, this study moves in the next part to elicit the methods followed in this study and to analyze the character of Mary psychologically. This analysis is going to be nurtured by the text's testimonies and quotes.

\section{Methods}

The paper at hand builds on the link between Mary's past events with her psychological conflicts and manifestations. The present study uses the theoretical technique of modern 
psychoanalysis as a conceptual framework to approach the character of Mary in Lessing's The Grass is Singing. On one hand, the present paper legitimates the title subject through linking psychoanalysis with literary works: psychoanalysis criticism. In other words, the subject title finds its legitimacy in the dominance of this current as a literary theory. This conceptual background to depart from for conducting the study stands on modern psychoanalysis and how it relates a person's psychological disorders to childhood events. Accordingly, various variables are taken into consideration while treating the character of Mary. The textual framework that nourishes the study is evidently the novel the Grass is Singing. The novel displays several elements that determined the life and the fate of Mary Turner, the protagonist. After demonstrating how psychoanalysis works and what it consists of, the study moves to apply this theory to Mary Turner. It attempts to diagnose Mary's character through delineating and analyzing different stage events of her life. Parents' carelessness and childhood events, bringing-up conditions, cultural and social impact and marriage challenges are looked at as independent variables. Mary's aggressiveness demonstrations and psychological neurotic displaying is approached as a direct effect of what she has been through since early infancy. It is, therefore, the dependent variable of the study.

\section{Findings}

The findings proved that Mary's childhood is a major determinant of her adult life psychological troubles and traumas. The sufferance she has been through as a child was restored in her unconscious in the form of memories and resurged up in due time as painful souvenirs. Study results also concluded that Mary's frustrations when she found out of how people perceived of her social status increased her neurotic problems. The present study proves that social and cultural norms can have great impact on individuals. Moreover, the paper reaches the conclusion that marriage decision has been devastating to Mary's life and was the proper room for Mary to have all her past life anguish brought to the front. The study ends by concluding that the abovementioned variables were essential causes for Mary's psychological aberrations, violent reactions to her servants and her contradictory feelings of love and hatred for the slave, Moses. Simply, her mental troubles and abnormal behaviors are products of her unconscious repressions. The latter themselves are end-results of real events in Mary's life: her childhood sufferance with a junky dad, sex abuse, affectionate abandonment, poverty and marriage failure.

\section{The Psychic Life of Mary Childhood}

The influence of childhood upon one's adult life is evident in psychoanalysis. Linking this approach to Mary's present life, it could be deduced that her childhood had strong impact on her mature personality. Her conflicting relationship with the society and the contradictory feelings she manifests can be interpreted as a product of her oppressed suffering childhood. As Mary has undergone a painful infancy at the view of her mother sufferings added to her childhood sexual abuse, her adult life became shaped by those tragic experiences and memories when they found the room to be surfaced. The appropriate room that allowed the recuperation of Mary's past anguish on the scene was her marriage with Dick Turner. Her unfortunate marriage, added to the poverty and disappointment she undergoes with Dick, takes her back into the past experiences that 
she has suppressed for a long time. Lessing (1950) stressing Mary's fears at the remembrance of her childhood,

..., when she thought of marriage, she remembered her father coming home red-eyed and fuddled; when she thought of children she saw her mother's face at the funerals - anguished but as dry and as hard as a rock (p. 28).

In this regard, Mary displays fears against becoming like her mother. Here, it is saliently expressed that Mary often associates her relationship with Dick in the village to her past life, which was characterized by poverty and the cruelty of her father. This is why, she becomes deeply depressed, and she sees her marriage as a serious mistake in her life because it leads her to live in poverty and loneliness just like she lived as a child. Her feeling of loneliness and isolation with Dick in the village takes her to the childhood memories. Mary's frustration aggravated when she was rejected by her old boss upon her attempt to go back to the town where she thought she would be happy. Therefore, she was obliged to accept her destiny, and she returns with her husband to the countryside. Thus, the image of her oppressing father, always dwelt her unconscious, was reembodied and reinforced with the concrete presence of Dick Turner. This is manifested in Lessing (1950) quote,

How the store smell made her remember the way she had stood, as a very small girl, looking fearfully up the rows of bottles on the shelves, wondering which of them her father would handle that night the way her mother had taken coins out of his pockets at night (p. 115).

Because of the hard experiences she had conducted in her past life added to those of the present with her husband, Mary manifests aggressiveness towards the others.

\section{Transference}

Transference is defined as a process of the transmission of feelings and reactions from the patient to the psychoanalyst. The patient sees his psychoanalyst as the return and the reincarnation of some important figure out of his childhood past. Consequently, he transfers to him his feelings and reactions (Kosciejew, 2012). Such transference is argued to be consisting of either affectionate feelings or hostile sentiments towards the other. In the case of Mary, she displays aggressive feelings against almost any one she comes across. It could be assumed that Mary exerts some sort of, psychologically speaking, Transference or Displacement. Prompted by social troubles and conditions, Mary's unconscious conflicts start exploding and surfacing. She displays much tirades and anger she transfers to her husband first and to all the farmers who worked under her supervision. She maltreats, nags at them, underestimates their services and even humiliates them by beating one of them, Moses. Lessing (1950) stresses, "(...) she beat him [Moses] down by two, feeling pleased with herself because of her victory over him" (p. 80).

Moreover, Mary enters a direct conflict with Moses when he came to her house and afflicts on him more torture. The narrator (1950) contends, “(...) she heard the complain that he had been working since five o'clock that morning with no food at all' (p. 94). Unlike Dick's treatment of the servants which is rarely cruel, Mary is cruel and offensive. She shows contempt for the natives

Arab World English Journal for Translation \& Literary Studies 
and finds them disgusting and animal-like. Mary sees Moses and the workers as obedient slaves who cannot resist. Although they do not lack physical power, they lack respect for their human dignity. Yet Mary's treatment of the black farmers shows her attempt to transfer her oppression and discharge it into those servants who cannot resist. Therefore, humiliating and taking away their human dignity could be regarded as a relative therapy for Mary's neurotic matters. This practice can be considered as a sort of exteriorizing the monster inhabited in the self of Mary. Psychologically approached, this form of hostility and repression towards the workers is a form of shifting her oppression to some people whenever there is an appropriate chance. It is not a purely racist act as much as it is a form of anger displacement. This is proved in Mary's overstated reactions to have fired all the house servants till there was none to accept working for her, but Moses.

This psychological motive of transference is clear because it is used abundantly in our modern societies. We often hear the formula, "Don't take it out on me" when we are arguing a certain matter with someone who seems to exaggerate in his verbal reaction. For example, someone may yell at us or engender verbal violence when the core issue to have brought the talk is not worthy that excessive reaction. In this case, we get aware that the speaker has a certain painful background (problems with another person he probably cannot face) which stimulates and fuels the talk in such a manner. For instance, Tyson (2006) states, "If you've ever told an angry friend "Don't take it out on me!" you were accusing that friend of displacement, which is the psychoanalytic name for transferring our anger with one person onto another person” (p. 11). This psychological interpretation could be convincingly applied to the situation of Mary. The problems she encounters with a failure husband against whom she cannot do much displaces them to the farm servants and particularly to Moses. Through this operation, she discharges her psychological problems into the others. However, in the presence of Moses at her home, the psychological situation of Mary was further agitated. Moses and her father images became ghosts who presented at her night dreams.

\section{Dream Interpretation}

Mary is attracted by Moses despite the fact that she shows him hatred and disgust. He was going to present in her dreams, mixed with the image of her father. The dream runs as follows as Lessing (1950) stresses,

He approached slowly, obscene and powerful, and it was not only he, but her father who was threatening her. They advanced together, and she could smell not only the native smell, but the unwashed smell of her father. It filled the room; musty like animals... he came near and put his hand on her arm. It was the voice of the African she heard. He was comforting her because of Dick's death, consoling her protectively, but at the same time it was her father menacing and horrible, who touched her in desire (p. 203).

In our dreams, the unconscious releases some of its repressed desires and expresses itself quiet freely. However, it is known that dreams come to us in different forms than how events truly happen in our lives. Even we often fail to find any interpretation of our dreams and sometimes we

Arab World English Journal for Translation \& Literary Studies 
tend to ridicule them, coming to us in meaningless inconsistent shapes and pictures. This inconsistency and incompatibility is what is called in psychological terms, Distortion.

Dreams are brought up in distorted forms for the safety of the dreamer. If it occurs that a person's dream represents events exactly as they happen in reality, the results would be dangerous and would create anxiety for the dreamer. Fortunately, the function of the dreams is just the opposite. That is, it aims to reduce anxiety and not increasing it. The purpose of dream work is generally held to transform the forbidden wish into a non-threatening form, thus reducing anxiety and allowing us to continuing sleeping (Jarvis, 2000). Therefore, dreams happen in distorted forms and sometimes are confused with different people in whom we may not be interested at all. Even we sometimes ignore the people who presented in our dreams. This is called Dream Displacement. In both situations, dream distortion and dream displacement aim at protecting us from horrible night visions. In the same interest, Tyson (2006) confirms, “(...) that protection [dream protection] takes the form of dream distortion; the message our unconscious expresses in our dreams, which is the dream's underlying meaning" (p. 18). On the other hand, displacement occurs when we identify with a loved person so as not to be frightened by the actual person whom we abhor. Tyson (2006) asserts, "Dream displacement occurs whenever we use a "safe" person, event, or object as a "stand-in" to represent a more threatening person, event, or object" (p. 18).

Once again, we can refer to dreams and how they are approached by psychoanalysis to understand the situation of Mary's dream. Freud explains dream displacement by a dream situation that occurred to one of his patients. One of Freud's patients was extremely resentful of his sisterin-law and used to refer to her as a dog, dreamed of strangling a small white dog. Freud interpreted this as representing his wish to kill his sister-in-law. If the patient had dreamed of killing his sisterin-law, he would have felt guilty. The unconscious mind transformed her into a dog to protect him (Jarvis, 2000). Based on this psychological dream interpretation, Mary's character can be referred here as having fused two characters in her dreams, that of her father and that of Moses, the black servant. Through the novel, it is evident that Mary was trying to get close to her father when her mother was absent. Meanwhile, she hated him as always coming home drunk and as having harassed her sexually. Similarly, Mary seems to unite Moses with her father, especially when she dreams that her husband dies, and she remains under threat because of something mysterious. This mixture between her black servant whom she once hits in the farm and her father may clarify her hatred to her father and her childhood at large.

\section{Individual vs. Collective Thought}

In this novel, Lessing discusses also the weight of culture and tradition upon the life of the individual. Mary sees herself before marriage as loved by all her friends, and she has never thought of getting married. She seems to have no psychological problems brought front because she is happy at her work, and she sees herself as a young and beautiful woman. As the narrator (1950) says, "She was very happy: that was her only positive quality, for there was nothing else distinctive about her, though at twenty-five she was at her prettiest" (p. 42). This means that she had been satisfied in her life, and she had never expected the distressing psychological state she endures at

Arab World English Journal for Translation \& Literary Studies 
present. She also chooses her clothes according to her taste, and she does not care about the external world as it is expressed in the words of the author (1950),

(...), and she still wore her hair-little girl fashion on her shoulders, and wore little frocks in pastel colors, and kept her shy, naïve manner. If she had been left alone, she would have been gone on, in her own way, enjoying herself thoroughly, until people found one day that she had turned imperceptibly into one of those women who had become old without ever having been middle-aged (p. 45).

Her first shock was when she hears her friends talking about her negatively and criticizing her state of staying unmarried as it is described by the author (1950),

(...), during those few months before she married, people were discussing her in a way which would have sickened her, had she suspected it. It seems hard that Mary, whose charity towards other people's failures and scandals grew out of a genuine, rock-bottom aversion towards the personal things like love and passion, was doomed all her life to be the subject of gossip (p. 51).

It was a big shock. Lessing (1950) stresses,

She was stunned and outraged; but most of all deeply wounded that her friends could discuss thus. She was so naïve so unconscious in her relation to other people that it had never entered her head that people could discuss her behind her back (p. 42).

This experience was going to change her life completely because she has never thought that her friends whom she loves can gossip about her in such a pejorative way. Because of the way she dresses and behaves, she was seen by her friends as a woman of thirties. In order to change her life style, her friends suggest as Lessing (1950) keeps describing the social pressure, "Why does not she marry? She must have had plenty of changes" (p. 48). This means for them that it is better for her to get married because most of women at her age are married. Consequently, Mary decides to get engaged with a man to avoid the embarrassment, in her friend's eyes, of staying single. In her desperation to mend her shattered and worn-out self-esteem added to the society pressure as elaborated above, Mary marries Dick Turner, the first man she comes across. In other words, she accepts to get married with Dick Turner whom she has never met before in order to satisfy this social demand of her friends and their sharp criticism.

This social-individual conflict for Mary can be analyzed according to the Freudian structural theory that divides human personality into three parts: Id, Ego and Superego. As it is mentioned before, the interaction between these components can lead to the development of both normal and abnormal behaviors. In the case of the protagonist, Mary, we can say that the Superego appears through her friend's authority and their negative impact on her life. Evidently, her friends represent the norms, the power of culture and its influence on individuals' decisions. These norms ought to be preserved and respected, especially in male-dominant societies (Herouach, 2020).

Arab World English Journal for Translation \& Literary Studies 
These socio-cultural rules that expect Mary to marry stand for the Superego. Mary subordinates not to the gossip of her friend's per see but to the social order that constrains individual freedoms. It is this socio-cultural collective authority and thought that exercises influence on Mary and not her friends as single bodies. In other words, the Superego judges her deeds and limits her individuality. As a reaction to this influence exerted by society, she hurries for marriage but ends up in despair and regrets. She develops inner conflicts striving between what she wants and what the society expects her to do.

Overall, when Mary discovers her real image as it is perceived by her friends, she is surprised, and she develops some feelings and behaviors which are going to be roughly influential on her psychological life. Because of sacrificing her individual choice for the collective thought, she is tormented with loneliness and lack of communication inside the marriage institution. Her marriage transports her back to the painful moments she had endured since very early. These childhood experiences have been buried in the unconscious for a long time. Having once gotten preoccupied with a job and the entitlement of herself as a busy pretty and loved woman, she distanced her childhood memories deep down into her unconscious. But as psychology proves, repressing our desires and conflicts doesn't mean eliminating them. Her husband failure added to the presence of her abhorred servant Moses at home, were to reincarnate the oppressed conflicts of an abused childhood from the recesses of her unconscious. Based on the aforementioned psychoanalysis techniques, this could lead us to assume that Mary is a victim of childhood experiences and repressions which took place in the unconscious, and were exploded later in her adult life at the occasion of marriage. It is in the midst of marriage conditions that her unconscious surfaced to punish her by refreshing all painful child memories of which she has become haunted.

\section{Mary and the Unconscious}

The unconscious is a central concept to psychoanalytic thinking. It is Freud's radical insight into the field of psychology. While the conscious contains all mental processes of which we are aware, the unconscious is defined as a reservoir of feelings and conflicts, thoughts and memories of which we are ignorant. Simply, the unconscious stores and keeps those unfulfilled wishes, repressed urges and motives, injuries and all those embarrassing situations in daily life. The most important of the Unconscious qualities lie in the fact that its repression for desires and conflicts remains active but of which humans are unaware. As Geraskov \& Asenov (1994) state, "The unconscious refers to the mental processes of which individuals make themselves unaware" (pp. 625-634). The unconscious, therefore, remains the deepest of the psychological structure of the human being. Freud described the depth of the unconscious in relation to the conscious with the iceberg. Clearly, the core of the iceberg represents the unconscious, whereas, the conscious is merely the surface of the iceberg. The bulk of the iceberg hidden under the water is the unconscious. Freud (1915) affirms that the conscious mind is seen just as the tip of the iceberg.

The unconscious mind, therefore, forms the greatest part of our psychological structure and, like the iceberg; we just cannot see it. However, Freud (1924) confirms that the preconscious thoughts and feelings can easily be brought to consciousness. This means that the conscious lies

Arab World English Journal for Translation \& Literary Studies 
just below the unconscious in symbolic distance and it could bring out the unconscious processes into conscious actions. Consequently, a great deal of our comportments and reactions can be explained by the pushing force of the unconscious. Applying this to Mary, the following could be generated: Mary, at the time she starts manifesting irritating reactions against almost all people she encounters, was not aware that the motives behind her violent actions could be referred to her psychological past. They could be manifestations of the unconscious that interpret all her oppressed desires into active actions. In other words, Mary's feelings of hatred, decisions of enslaving cruelly the servants and Moses and the entire violent psychological motives she displays at her present life are powerfully influenced by her past experiences which were stored ever since in her unconscious. Tyson (2006) affirms the working mechanisms of the unconscious, "The unconscious is the storehouse of those painful experiences and emotions, those wounds, fears, guilty desires and unresolved conflicts we don't want to know about because we feel we will be overwhelmed by them" (p. 12). Clearly, the unconscious helps distancing away all memories, identifications and events by which we can get eventually self-defeated. On the other hand, Mary's renouncement to get married may be psychologically explained as "Fear of Intimacy". For example, Tyson (2006) holds,

Fear of intimacy - the chronic and overpowering feeling that emotional closeness will seriously hurt or destroy us and that we can remain emotionally safe only by remaining at an emotional distance from others at all times. As we saw above, fear of intimacy can also function as a defense; if this particular defense occurs frequently or continually, then fear of intimacy is probably a core issue (p. 16).

The wounding experiences she had undergone with her father minded her from marriage in fear to be restored with another man. Yet those memories came back eventually when she was disappointed in her friend's friendship and decided to marry out of social pressure. As a result, her entire unconscious unpleasant memories were being laid the ground for re-surfacing. After her marriage with him, Mary is reluctant towards physical relationship with Dick. She dislikes physical intimacy with her husband because she dreads that it may produce feelings that she does not want to experience. Sexually, Mary is represented as rigid in her relations and is not sexy at all. That's to say, her being sexually molested as a child by her father could be seen as a determining factor for her fears and anxiety about sex, marriage and motherhood. The social and sexual aberrations she underwent as an infant determined a great deal of her present actions. Her unconscious stored all the abuse she underwent and displayed it at her adult life. Sexual harassment by her own father made her disliking sex because she associated it with anguish and pain. That is why; she does not show any sexual attraction towards her husband.

Those hidden processes for long years had to be evoked by unconscious determinism because psychoanalysis informs us that our oppressed desires and conflicts are not ultimately omitted. Tyson (2006) asserts,

Repression does not eliminate our painful experiences and emotions; rather, it gives them force by making them the organizers of our current experience; we unconsciously behave 
in ways that will allow us to play out without admitting to ourselves, our conflicted feelings about the painful experiences and emotions we repress (pp. 12-13).

This means that the unconscious is not merely a passive reservoir that keeps those conflicts stored indefinitely. At some point in life, unless exposed for a therapy, those repressed unconscious processes may appear and be surfaced in different forms. They could be manifested in neurotic, hysteric and various psychological problems. Such neurotic matters, if not cured and dealt with properly, could very possibly lead to serious behaviors, including crimes, sexual deviations and violent reactions to the surrounding. Thus, all the oppressed desires and conflicts of the hurtful past of Mary were brought to the front when stimulated by certain conditions in her adult life. She was acting upon them, displaying irritation, violence and overstated reactions, which draw her to her ultimate end.

\section{Mary and Death}

Mary eventually realizes that Moses is seeking revenge on the subordination he used to bear and the humiliation he underwent by her. Mary finally confesses and laments her psychic situation as stated by Lessing (1950),

It's a long time since I came here. [...], so long that I can't quite remember...I should have left long ago. I don't know why I didn't. I don't know why I came. But things are different, very different. ... I don't know anything. I don't understand. Why is this happening? I didn't mean it to happen. But he won't go away, he won't go away" (p. 232).

Moreover, when Moses finds out that Dick and Mary are leaving the farm forever, he becomes desperate to regain his lost sense of power over her and aches to inflict the ultimate form of punishment by killing her. Yet Mary perceives that her life wasn't worthy of leaving either as she has always been hollow, sterile and dry. She recalls her mistakes and realizes her passivity, her being distant from life as Lessing (1950) argues, "The sky was luminous; but there was an undertone of cold grey; the stars were bright; but with a weak gleam" (p. 235). She discovers her detachment from the world, the surrounding though she had spent so many years amidst them and she is overwhelmed as the writer (1950) puts, "The world was a miracle of color and all for her, all for her, she could have wept with release and light-hearted joy" (p. 238). She experiences the ultimate indifference, her indifference towards her own life. Her eventual exit seems to embody in death itself. She does not have to undergo any more suffering and awaits her ultimate freedomdeath calmly. Lessing (1950) confirms "(...) as if there was nothing new in her death" (p. 248). Actually, Moses and her nearing death seem to her to be the only means of rescue. She passively chooses to accept the coming death.

In her desperate struggle to fight with complete submission and oblivion, Mary Turner is constantly seen to wage a war between the real and the unreal in the last part of the novel. In her relentless struggle to regain her entity and her lost sense of control over her own life, Mary

Arab World English Journal for Translation \& Literary Studies 
Turner is undergoing severe turmoil where at some junctures she desires to submit to her fate. Lessing (1950) in this regard puts,

She ran outside: what was the use of sitting there, just waiting, waiting for the door to open and death to enter? She walked straight into the bush, thinking: I will come across him, and it will all be over" (p. 243).

Mary is finally murdered, stressed by very expressive statements of Lessing (1950),

She opened her mouth to speak; and, as she did so, saw his hand, which held a long curving shape, lifted above his head; and she knew it would be too late. All her past slid away, and her mouth, opened in appeal, let out the beginning of a scream, which was stopped by a black hand inserted between her jaws. But the scream continued, in her stomach, choking her; and she lifted her hands, claw like, toward him off (pp. 254-255).

Yet Mary seems to submit for death as the author (1950) confirms, "But then, what is madness, but a refuge, a retreating from the world?" (p. 232). Death here can be symbolically represented as Mary's ultimate psychic degeneration and escape as she fades away in complete oblivion and passivity that signifies an absolute detachment from reality. She seems to have accepted and even celebrated death that convincingly supports the arguments debated above of her troubled psychological situation.

\section{Discussion}

From the above-covered concepts in due relation to psychoanalysis and psychoanalysis criticism, Mary's character is displayed to the front. Aided by psychoanalysis techniques, Mary's psychological motives and manifestations are diagnosed and spotlighted. Psychology believes at first hand that Sexuality is regarded as a natural instinctual energy that highly determines the growth of personality. Based on Freud's psychological studies and diagnoses of his patients, passing the psychosexual stages successfully or unsuccessfully is what delineates the nature of adult personality. In the case of Mary Turner, the text provides the reader with a clear image of Mary's infancy: she was sexually harassed by her drunkard dad and was often affected by the violence that was exerted on her mother by her father. In other words, she failed to pass the psychosexual stages in healthy conditions. These painful experiences were not omitted by time. Psychology informs us that repressing our desires, fears and motives in the unconscious doesn't mean eliminating them.

The unconscious is regarded as a reservoir of feelings, desires, conflicts, thoughts and memories of whose presence we are ignorant. The unconscious harbors and stores those motives to re-appear in due time. Freud described the depth of the unconscious in relation to the conscious with the iceberg. The bulk of the iceberg hidden under the water is the unconscious, whereas, the conscious is merely the surface of the iceberg. Therefore, Mary's present behaviors and feelings could be regarded as projections of her unconscious repressed conflicts and manifestations of the unconscious that interpret all her oppressed desires into active actions. That is why, she developed 
a set of psychological traumas like anger, anxiety, isolation, aggressiveness...etc. In other words, her adult life character reactions are considered end-results of the explosion of her unconscious into physical behaviors. Her unconscious repressions climaxed and needed a room to burst.

Moreover, the socio-cultural pressure exerted a significant influence on Mary's decisions. Mary's friends' gossip against her singleness represents the authority of socio-cultural norms. The ideal woman in the point of view of patriarchal societies is the woman who meets the socio-cultural expectations. If these norms are opposed and resisted, these women are considered against the stream and against the supposedly accepted norms; henceforth, receiving much cultural insulation and symbolic violence from the surrounding people (Herouach, 2019). Thus, Mary's housemates represent the social order. Mary submits to the socio-cultural system and its rules not to the gossip of her friend's per see. Consequently, she decides to get married with the first man she encounters, Dick Turner. Mary's fate with Dick Turner was a reincarnation of a screwed-up family version that Mary lived in with her parents. Mary displays fears against reproducing her mother version, leading to a failure marriage. She doesn't show any sexual attractiveness to him. She experiences a sort of Coitophobia. This fear of sexual intimacy could be determined by the sexual harassment she underwent as an infant. Sexual harassment by her own father made her disliking sex because she associated it with anguish and pain. Therefore, her marriage decision was another mistake in her life. It was transporting her back to the painful moments she had endured since very early. Her husband failure added to the presence of her abhorred servant Moses at home, were to reincarnate the oppressed conflicts of an abused childhood from the recesses of her unconscious.

As a result, Mary is found to be behaving hysterically to her surroundings. The stored souvenirs and memories, repressed desires in the unconscious were being manifested in neurotic and hysteric problems. Transforming her irritation to her entourage members, her husband and the servants, Mary is regarded psychologically as exercising mental discharging. She releases her experienced anxieties through taking them out on others. Humiliating the farmers serves as a relative therapy for Mary's neurotic matters. Psychologically approached, this form of hostility and repression towards the workers is a form of shifting her oppression to some people whenever there is an appropriate chance. It is a sort of anger transference and displacement. Mary overreacted and expelled all servants coming to her house until she collides with Moses who exchanged her hatred and determines to take revenge and murder her. Yet Mary perceives death like the opportunity she was looking forward to. She admits that her life was not worthy of leaving and recognizes her mistakes and realizes her passivity. She reproaches herself and tortures her mind on the tragedies she had to undergo.

Therefore, face to death, she is thrilled and experiences an ultimate indifference. Her eventual exit seems to embody in death itself. She does not have to undergo any more suffering and awaits her ultimate freedom-death calmly. She yields and submits to and embraces welcomingly death. The last words she spelled when she perceived of death close were a strong sign of a final sought salvation, a chill, an end to all her miseries. In overall, Mary's chill towards death could represent the Thanatos in Freud's account or the death instinct that seeks to terminate life in contrast to Eros instinct which seeks to perpetuate it. Freud's words seem to echo here,

Arab World English Journal for Translation \& Literary Studies 
"The aim of all life is death" (as cited in Hergenhahn, 2009, p. 533). Death instinct was activated and sought by Mary to end to all her life-long suffering.

\section{Conclusion}

The study has delineated the factors that were behind Mary's psychological disorders and perversions. In other words, the present study has answered the research problem: the rationale behind Mary's troubled mental and hysterical manifestations. As the study proved, Mary's present and adult demeanors were determined by several factors: her painful infancy, the social stigmatization of her as an unmarried girl, the weight of culture represented by her friends and the marriage failure that gave rebirth to all her unconscious repressed conflicts.

Overall, it could be assumed that Doris Lessing (1950) has managed to step deeply into the inner feelings and thoughts of her characters, mainly of Mary. In other words, she succeeded to impart a psychological dimension on her work The Grass is singing. Lessing (1950) was so conscious of psychology to have depicted the complex mind of a woman, Mary in psychological terms and backgrounds. Moreover, the author proved of sociological acquaintance in having described the society's burden on the individual. As seen before, the concept of Marriage is represented as a changing point in the life of Mary because it leads her to face her reality as a mature woman. Moreover, marriage was also the determining factor behind all the psychological changes she has undergone in the village of loneliness and solitude.

In other words, after marriage, the repressed memories and feelings of Mary find the village as a suitable environment in which they are brought into the surface. Because of isolation and lack of communication, Mary was taken back into her childhood when she endured severe events in her relationship with her parents, particularly, her abuser father. Briefly, the accumulated suffering experiences of Mary since infancy were stored as sad memories in her unconscious mind. Such memories were exteriorized in her later life and manifested in neurotic forms and psychological troubles, reinforced by the presence of her failure husband, and her abhorred servant, Moses. These psychological pathologies push her to treat the black servants in a hostile manner and transfer into them her mental troubles that led, in turn, to her tragic end.

\section{Implications}

Thanks to the groundbreaking works of Freud and his established theory that we have become today familiar with many psychological terms. We use them in our real life and we reach to explain many of our actions psychologically and those of our peers. That is no surprise because it is the function of Psychoanalysis to help us understand the human behavior. Since fiction and literary works represent a great deal of human behaviors, psychoanalysis can help understanding these literary texts. Lessing' work, The Grass is Singing (1950) with emphasis on the personage Mary is a significant example of a literary work enticing researchers to approach it from a psychoanalytic perspective. Lessing work motivates us to take in consideration psychoanalysis while treating literary texts. When we investigate into Mary's psychological conflicts, which are referred to her childhood sufferings, on one hand and to her marriage imposed by social pressure on the other; we understand her present psychological projections.

Arab World English Journal for Translation \& Literary Studies 
Moreover, the work may inform the reader about a certain state of mind of the author. It unravels the psychological motives of the writer that find their appropriate room into fictional forms, which cannot be expressed otherwise. In other words, written art may be expressive of the secret unconscious feelings, desires, and anxieties of the artist. It is an appropriate scope where the author releases his unconscious impulses and repressed conflicts. That is the function of Psychoanalytic criticism. It focuses on the extent to which literary works are likely to reflect the psychological dimension of the author, embodied in personages and characters. Mary, a female protagonist, could be a projection of the author's psyche itself. The character of "Mary", therefore, may demonstrate strong signs for understanding the psychic life of the Author, Doris Lessing.

\section{About the Author:}

Sofian Herouach is a Ph.D. candidate. He conducts research in the field of Social and Human Sciences at the Faculty of Arts and Humanities, Dhar El Mehraz, Fes, Morocco. So far, he has accomplished a number of published works in indexed journals such as ESJ and Open Political Science Journal of Die Gruyter. Moreover, he is an active member in the educational sector, working as an ESL high school teacher. https://orcid.org/0000-0003-2266-3668.

\section{References}

Abrams, M. H. (1999). A glossary of literary terms. California: Harcourt Brace College Publishers.

Appleman, D. (2015). Critical Encounters in Secondary English: Teaching Literary Theory to Adolescents. New York: Teachers College Press.

Bagchi, N. (2015). The Reality of the Fractured Psyche as Represented in "Grass Is Singing". Science Publishing Group: Social Sciences Journal, 9-13.

Basler, R. P. (1975). Sex, Symbolism and Psychology in Literature. Michigan: University of Michigan: Octagon Books.

Bullock, A., \& Trombley, S. (1999). The New Fontana Dictionary of Modern Thought. London: Harper Collins.

Bullough, V. L., \& Bullough, B. (1994). Human Sexuality, an Encyclopedia. Abingdon: Routledge.

Carducci, B. J. (2009). The Psychology of Personality: Viewpoints, Research, and Applications. Chichester: Wiley-Blackwell.

Cherry, K. (2019, October 19). Theories. Retrieved July 5, 2020, from Very Well Mind: https://www.verywellmind.com/what-is-the-id-2795275

Coyne, R. (1999). Technoromanticism: digital narrative, holism, and the romance of the real. Cambridge: Cambridge Mass: MIT Press.

Das, B. K. (2005). Twentieth Century Literary Criticism. New Delhi: Atlantic Publishers \&Distributers.

Arab World English Journal for Translation \& Literary Studies 
AWEJ for Translation \& Literary Studies Volume, 4 Number 4. October 2020

A Psychoanalysis Reading of Mary Turner's Character in Lessing's The Grass is Singing

Herouach

Freud, S. (1924). A General Introduction to Psychoanalysis. (G. S. Hall, Trans.) Books World.

Freud, S. (2014). On the Sexual Theories of Children. Worcestershire: Read Books Limited.

Freud, S. (2005). Dream Psychology: Psychoanalysis for Beginners. New York: The James A. McCann Company.

Freud, S. (1915). The Unconscious. (G. Frankland, Trans.) London: Penguin.

Freud, S. (2015). Three Contributions to the Theory of Sex. (A. A. Brill, Trans.) New York: Create Space Independent Publishing Platform Freud, S. (1923). The ego and the id. London: Hogarth Press.

Freud, S., \& Breuer, J. (2004). Studies in Hysteria. London: Penguin Classics.

Geraskov, \& Asenov, E. (1994). The internal contradiction and the unconscious sources of activity. Journal of Psychology, 625-634.

Godley, G. a. (2006). Inheritance in Psychoanalysis. New York: Suny Press.

Harris, L., \& Scott, M. (1984). Shakespearean criticism: excerpts from the criticism of William Shakespeare's plays and poetry, from the first published appraisals to current evaluations. Michigan: Gale Research Company.

Hergenhahn, B. R. (2009). An Introduction to the History of Psychology. Wadsworth: Wadsworth Cengage Learning.

Herouach, S. (2019). Liberal Feminism Impact on Moroccan Educated Women: Faculty of Letters and Human Sciences, FLDM, as a Field Study. Open Political Science, 128-152.

Herouach, S. (2020). Patriarchy and Spinsterhood in Morocco, Faculty of Letters and Human Sciences, Dher el Mehrez, Fes, as a Case Study. International Journal of Contemporary Research and Review, 21711-21736.

Jarvis, M. (2000). Theoretical Approaches in Psychology. London: Routledge.

Kosciejew, R. J. (2012). The Designing Theory of Transference (Vol. I). Author house.

Lessing, D. (1950). The Grass is singing. London: Michael Joseph (UK) Thomas Y. Crowell Co. (US).

Louw, D., Ede, D., \& Louw, A. (1998). Human Development. Cape Town: Kagiso Tertiary.

Mcleod, J. (2003). An Introduction to Counselling. London: Open University Press, McGraw-Hill Education.

Montgomery, \& al, e. (1992). Ways of Reading: Advanced Reading Skills for Students of English Literature. London: Routledge.

Pannenberg, W. (1985). Anthropology in Theological Perspective. London: T \& T Clark International.

Parackal, S., \& Panicke, R. (2019). Children and Crime in India: Causes, Narratives and Interventions. London: Palgrave Macmillan. Retrieved 2020, from Simply Psychology:

Arab World English Journal for Translation \& Literary Studies

ISSN: 2550-1542 | www.awej-tls.org 
AWEJ for Translation \& Literary Studies Volume, 4 Number 4. October 2020

A Psychoanalysis Reading of Mary Turner's Character in Lessing's The Grass is Singing

https://www.simplypsychology.org/psyche.html.

Plutchik, R. (1980). Theories of emotion (Vol. 1). Virginia: Virginia Academic Press.

Randall, R. (1989). Freedom and Taboo: Pornography and the Politics of a Self-Divided. Berkeley: California Press.

Shaffer, D. R. (2009). Social and Personality Development. California: Wadsworth.

Szeman, I., \& O'Brien, S. (2017). Popular culture: a user's guide. New Jersey: john wiley \& sons.

Thurschwell, P. (2000). Sigmund Freud. Abingdon-on-Thames: Routledge.

Tidd, U. (2004). Simone de Beauvoir. London: Routledge.

Tyson, L. (2006). Critical Theory Today. Abingdon: Routledge.

Yahya, W. (2010). A Socialist Feminist Reading of Doris Lessing's the Grass is Singing. The International Journal of the Humanities, 2-12.

Zhang, Y. (2017). An Interpretation of Mary in the Shadow of Colonialism in Doris Lessing'sThe Grass is Singing. Canadian Center of Science and Education, 55-60. 